\title{
Peran Pesantren sebagai Implementasi Community Civics di Pesantren Nahdlatul Ulama
}

\author{
Zindan Baynal Hubi ${ }^{1}$, Rizal Fahmi, Aisha Nadya, Nursanda Rizki Adhari \\ Pendidikan Ekonomi, Fakultas Keguruan dan Ilmu Pendidikan, Universitas Islam Syekh Yusuf, \\ Tangerang, Indonesia \\ 1'zindanbayna@@unis.ac.id
}

\begin{abstract}
ABSTRAK
Artikel ini membahas peran Nahdlatul Ulama (NU) sebagai implementasi pendidikan kewarganegaraan kemasyarakatan (community civics) dengan basis kulturalnya yaitu pesantren dalam membina dan membentuk warga NU (Nahdliyin) agar menjadi warga negara yang baik dan cerdas. Community civics merupakan domain sosiokultural Pendidikan Kewarganegaraan (PKn) yang dilakukan di luar pendidikan formal (deformalisasi) serta berkembang di masyarakat melalui organisasi sosial kemasyarakatan, organisasi politik, lembaga swadaya masyarakat, institusi, dan perusahaan. Penelitian ini menggunakan pendekatan kualitatif, dengan wawancara dan observasi sebagai teknik pengumpulan data guna mendapatkan hasil yang mendalam. Adapun metode yang digunakan berupa studi kasus di Pesantren Nahdlatul Ulama Al-Hikamussalafiyah Cipulus Purwakarta. Hasil penelitian ini menunjukkan bahwa Nahdlatul Ulama dengan pesantren yang dinaunginya telah mampu menjadi teladan pelaksanaan community civics. Implementasi tradisi ilmu keagamaan mampu disinergikan dengan konteks keindonesiaan dalam membentuk karakter warga Nahdliyin dan santri khususnya di lingkungan Pesantren Al-Hikamussalafiyah. Modal kultural tersebut berupa sikap tawassuth (tengah/moderat), i'tidal (tegak lurus) tasamuh (toleransi), tawazun (seimbang), dan amar ma'ruf nahi munkar (menegakkan yang benar dan melarang yang salah). Modal ini berdasar pada tradisi keagamaan yang menjadi sebuah legitimasi utama dalam mensyiarkan risalah Islam sebagai rahmat bagi seluruh alam semesta (Islam rahmatan lil 'alamin). Pada akhirnya para santri bisa memahami, menganalisa, dan menjawab masalah-masalah sosial yang dihadapi baik di masyarakat dan bernegara secara berkesinambungan serta berperan dalam menciptakan Indonesia sebagai negara idaman yang selaras kebaikan alam dan masyarakatnya (baldatun thayyibatun wa rabbun ghafuur).
\end{abstract}

Kata kunci: peran pesantren, Nahdaltul Ulama (NU), pendidikan kewarganegaraan kemasyarakatan (community civics)

\section{ABSTRACT}

This article explains the role of Nahdlatul Ulama (NU) as an implementation of community civics with Islamic boarding school (pesantren) as its cultural base, in fostering and shaping the NU community (Nahdliyin) to become good and smart citizens. Community civics is a socio-cultural domain of Civic Education which is implemented beyond the formal education at school (deformalization) and develops in the community through social organizations, political organizations, non-governmental organizations, institutions, and companies. The study used a qualitative approach, with interviews and observations as data collection techniques in order to obtain in-depth results. The method used is a case study at the Nahdlatul Ulama Islamic Boarding School Al-Hikamussalafiyah Cipulus Purwakarta. The results indicate that Nahdlatul Ulama and its supported Islamic boarding school have been able to become a role model in implementing community civics. Religious knowledge 
tradition blended with Indonesian identity is implemented in shaping the characters of Nahdliyin community and students, particularly at the Al-Hikamussalafiyah Islamic Boarding School. The cultural values are tawassuth (moderate), i'tidal (straight), tasamuh (tolerant), tawazun (balanced), and amar ma'ruf nahi munkar (enjoining what is right and forbidding what is wrong). The values are based on religious tradition which is the main legitimacy in spreading the message of Islam for the good of all human beings (rahmatan lil 'alamin). In the end, the students can understand, analyze, and answer social problems in the society and the nation in a sustainable manner and play a role in building Indonesia as an ideal state with good citizens and natural resources (baldatun thayyibatun wa rabbun ghafuur).

Keywords: Islamic boarding school (pesantren), Nahdaltul Ulama (NU), community civics

This work is licensed under the Creative Commons Attribution-ShareAlike 4.0 International License. (C2021 by the author(s).

\section{PENDAHULUAN}

Setiap negara mempunyai visi dan misi untuk kebaikan dan kemajuan warga negaranya. Pembentukan karakter warga negara yang baik dan cerdas, taat hukum, demokratis, partisipatif, memiliki rasa cinta tanah air, dan kompeten menjadi orientasi pembangunan ke depan. Oleh sebab itu diperlukan program pendidikan yang bertujuan untuk membentuk warga negara sebagaimana yang diharapkan. Salah satu cara yang ditempuh adalah melalui program kurikuler di lembaga pendidikan. Di Indonesia, pembentukan karakter warga negara yang baik dan cerdas dilakukan melalui sebuah program kurikuler mata pelajaran/mata kuliah Pendidikan Kewarganegaraan (PKn). Kedudukan pelajaran tersebut menjadi sangat penting dalam pembinaan karakter warga negara terutama pengembangan kecerdasan kewarganegaraan (civic intelligence).

Perlunya PKn tidak terlepas dari dasar epistimologis mata pelajaran ini yang merupakan pendidikan andragogi untuk mendidik warga negara muda dalam memahami perannya sebagai warga negara. Secara sosio-pedagogis, PKn mengembangkan potensi individu sebagai insan Tuhan dan makhluk sosial sehingga tercipta warga negara yang baik dan cerdas.

PKn memiliki tiga domain, yakni domain kurikuler (PKn sebagai mata pelajaran di sekolah), domain sosiokultural (PKn yang berkembang di masyarakat yang dimediasi oleh organisasi, media massa, lembaga dan lainnya), dan domain kajian ilmiah (kegiatan penelitian dan pengembangan program-program $\mathrm{PKn}$ ) (Winataputra, 2012). Hal itu dikuatkan oleh Praja (2015) yang mendefinisikan PKn sebagai sistem pengetahuan yang bersifat "pre-pradigmatik" yang memusatkan kajiannya pada multidimensionalitas perilaku kewarganegaraan dan budaya kewarganegaraan pada tataran filosofis, ilmiah, kurikuler dan sosiokultural.

Muatan materi PKn saat ini tidak cukup hanya mengandalkan faktor negara saja sebagai pendorong. PKn perlu didorong lebih jauh menjadi sesuatu yang bersifat deformalistis melalui organisasi masyarakat dan komunitas sosial, sehingga setiap institusi, lembaga swadaya masyarakat, perusahaan, organisasi kemasyarakatan, dan komunitas memiliki peran dan tanggung jawab dalam 
membangun kompetensi warga negara itu sendiri. Di sinilah seharusnya peran bersama segenap warga bangsa ikut andil dan hadir saling mengisi kompetensi yang belum tercapai. Peran tersebut setidaknya berpengaruh dalam fundamen kehidupan bersama sebagai sebuah bangsa untuk mencapai tujuan yang telah dicitacitakan dalam pembukaan Undang-Undang Dasar Negara Republik Indonesia Tahun 1945.

Dewasa ini kesadaran berbangsa dan bernegara mulai luntur dari dua arah yaitu globalisasi dan fundamentalisme ideologis (Suseno, M, 2006). Apabila kita cermati beberapa tahun terakhir fundamentalisme ideologis tersebut menguat dan menyeruak ke permukaan diskursus ruang publik dan masyarakat. Hal itu tidak bisa terelakkan akibat kontestasi realitas politik yang tidak mengedukasi dan cenderung mengedepankan kepentingan kelompok.

Globalisasi yang tidak terelakkan dengan segala bentuk kecanggihan teknologi telah membawa pemahaman yang tidak sesuai dan mulai menggerus jati diri bangsa di ranah sosial kemasyarakatan. Kehidupan kebangsaan yang telah ditata dengan sedemikian baiknya oleh para pendiri bangsa hari ini dihadapkan dengan menurunnya moralitas masyarakat, lunturnya nilai-nilai nasionalisme dan kebangsaan, terabaikannya identitas nasional, meningkatnya konflik antar etnis, ras dan agama, serta semakin menguatnya isu disintegrasi bangsa. Dengan demikian, di tengah berbagai masalah bangsa, kejernihan berpikir dan bersikap sangat diperlukan.

Melihat spektrum ancaman yang terus berubah, maka dirasa perlu deformalisasi Pendidikan Kewarganegaraan, yaitu pengembangan kesadaran kewarganegaraan yang dilakukan di luar jenjang sekolah formal. Sudah selayaknya berbagai elemen bangsa ikut sadar sepenuh hati dan telibat dalam menyemai kesadaran berbangsa dan bernegara dalam masyarakat agar tercipta warga negara yang baik dan cerdas.

Permendagri Nomor 71 Tahun 2012 tentang Pedoman Pendidikan Kebangsaan Pasal 4 menyebutkan bahwa penyelenggaraan pendidikan wawasan kebangsaan dan menjadikan warga negara yang baik salah satunya ditujukan kepada organisasi kemasyarakatan atau lembaga nirlaba. Organisasi kemasyarakatan diperlukan dengan maksud untuk mengoptimalkan pengembangan dan pelaksanaan nilai kebangsaan guna memberdayakan kesadaran berbangsa dan bernegara.

Menanamkan pemahaman kebangsaan di Indonesia serta membentuk karakter warga negara yang baik dan efektif dalam kehidupan masyarakat juga merupakan tanggung jawab organisasi kemasyarakatan. Salah satu organisasi kemasyarakatan yang berbasis sosial-keagamaan yang aktif berperan dalam menanamkan kesadaran kebangsaan dan membentuk karakter warga negara yang baik adalah kalangan tradisionalis dari Nahdatul Ulama atau yang disebut nahdliyin. Dalam kajian akademis tentang modernisasi Indonesia, NU yang tradisionalis dengan basis kultural pesantren seringkali ditampikkan peranannya, berbanding terbalik dengan lembaga pendidikan Islam lain yang dikelola dan berafiliasi dengan kalangan keorganisasian Islam modern.

Oleh karena itu, penelitian ini ditujukan untuk mengkaji dan menjelaskan 
peran NU, khususnya pesantrennya, di tengah masyarakat sebagai organisasi sosial kemasyarakatan, termasuk peran yang dilakukan dalam kehidupan bermasyarakat, berbangsa dan bernegara dalam domain deformalisasi PKn melalui community civics. Hasil penelitian ini diharapkan mampu memahami, menganalisa, dan menjawab masalah-masalah yang dihadapi masyarakat, bangsa dan negara secara berkesinambungan, terutama dengan mengkaji metode yang telah dilakukan di pesantren.

\section{METODE PENELITIAN}

Penelitian ini menggunakan metode kualitatif yang lebih menekankan pada kedalaman data bukan pada banyaknya data. Selain itu kajian penelitian ini bersifat "alamiah, dengan lebih memperhatikan fenomena yang ditelitinya sebagaimana adanya dan bukan sebagaimana seharusnya" (Muchtar, 2006). Dengan menggunakan metode studi kasus, penelitian ini diharapkan dapat menyelidiki fenomena kontemporer yang terdapat dalam konteks kehidupan nyata, yang dilaksanakan ketika batasan-batasan antara fenomena dan konteksnya belum jelas, dengan menggunakan berbagai sumber data (Yin, K, 2011).

Fenomena yang dikaji adalah peran pesantren sebagai sebuah gerakan community civics yang mampu mendeformalisasi Pendidikan Kewarganegaraan dalam konteks kehidupan sosial kemasyarakatan dengan berbasis komunitas. Lokasi penelitian ini bertempat di Pesantren Al-Hikamussalafiyah, Cipulus, Purwakarta. Pesantren ini dipilih karena merupakan salah satu pesantren tertua di Jawa Barat dan berafiliasi dengan Nahdlatul Ulama, sehingga cocok untuk mengkaji bagaimana peran NU sebagai kelompok masyarakat dan komunitas kewarganegaraan dalam pemberdayaan berbasis kultur dan pranata sosial.

Subjek penelitian meliputi pengasuh pesantren/Dewan Kyai sejumlah tiga orang, Pengurus Am lima orang, dan para santri delapan orang. Data didapatkan melalui wawancara, observasi, dan kajian literatur. Wawancara dilakukan secara mendalam untuk menggali peran pesantren dalam dalam kehidupan sosial kemasyarakatan dan kebangsaan. Objek observasi yaitu kegiatan-kegiatan di lingkungan pesantren, sementara kajian literatur difokuskan kepada kultur dan budaya pesantren. Teknik analisis data yang digunakan yaitu reduksi data, penyajian data, dan penarikan kesimpulan/verifikasi. Validitas data dilakukan untuk membuktikan kesesuaian antara penelitian dengan dunia nyata.

\section{HASIL PENELITIAN DAN PEMBAHASAN}

\section{Deformalisasi Pendidikan Kewarganegaraan Melalui Implementasi Community Civics}

Community civics merupakan kajian di bidang kewarganegaraan untuk membentuk warga negara yang baik dan cerdas, cinta tanah air, berkarakter, kompeten, demokratis, toleran serta mampu memahami, menganalisa, dan menjawab masalah-masalah yang dihadapi oleh masyarakat, bangsa dan negara secara berkesinambungan. Hal ini juga sejalan dengan pernyataan (Budimansyah, 2010) bahwa untuk membangun karakter bangsa, PKn harus memainkan peran sebagai program kurikuler pada lembaga pendidikan formal maupun nonformal, sebagai gerakan sosiso-kultural kewarganegaraan, dan sebagai pendidikan politik kebangsaaan bagi para penyelenggara negara, pimpinan dan anggota organisasi 
sosial serta organisasi politik. Ketiga peran tersebut harus dilihat sebagai satu kesatuan yang tidak bisa dipisahkan.

Community civics merupakan sebuah cabang studi kewarganegaraan yang menekankan hubungan individu dengan lingkungan sosialnya yang dipahami sebagai komunitas yang terus berkembang, baik di tingkat daerah maupun di tingkat nasional (Good, 1959). Pada intinya, gerakan community civics menitikberatkan kepada pencerdasan warga negara dimulai dari lingkungan terdekat yang ditopang dengan kesadaran bersama. Gerakan ini memiliki misi mempersiapkan generasi muda untuk mengembangkan pengetahuan dan skill dalam membangun komunitas dengan memfokuskan pada keterlibatan warga sebagai salah satu bentuk tanggung jawab warga (Rusnaini, 2018).

Hal tersebut selaras dengan pandangan Emile Durkheim (Lubis, F, A, 2006), bahwasanya "before all else is an active cooperation" (yang paling utama adalah kerja sama aktif). Oleh karena itu pencerdasan dan pembentukan warga negara yang berkarakter menjadi tanggung jawab bersama warga bangsa untuk menjangkau seluruh lapisan sebagai pertanggungjawaban warga negara. Adapun materi community civics menurut (Rohani, 2015) "terdiri dari pendidikan kewarganegaraan (civic education), pendidikan demokrasi, dan literasi kewarganegaraan (civic literacy) yang merupakan pendidikan moral dan pendidikan tingkah laku sosial".

Metode kegiatan yang dapat dilaksanakan di tengah masyarakat bisa berbagai macam, contohnya di bidang keorganisasian yaitu sistem pengkaderan, seminar, dan pemberdayaan. Metode kegiatan juga dilakukan melalui institusi agama seperti metoda dakwah, uswah atau suri tauladan, dan metode latihan melalui program civic mission" (Sumantri, 2010).

Dari gagasan tersebut dapat dimaknai bahwa Pendidikan Kewarganegaraan melalui domain sosial kultural kemasyarakatan memiliki peran penting dalam membentuk karakter bangsa dan membina warga negara Indonesia agar menjadi warga negara yang memahami tugas dan tanggung jawabnya dalam kehidupan berbangsa dan bernegara. Melalui Pendidikan Kewarganegaraan, "warga negara diharapkan mampu memahami, menganalisa, dan menjawab masalah-masalah yang dihadapi oleh masyarakat, bangsa dan negara secara berkesinambungan demi mewujudkan cita-cita dan tujuan yang telah digariskan dalam Pembukaan UUD Negara Republik Indonesia Tahun 1945" (Ahadi, 2017).

Community civics apabila dianalogikan hampir sama dengan pendidikan politik yang yang dijelaskan oleh Branson (1998), bahwasanya demokrasi bukanlah sebuah mesin yang akan berfungsi dengan sendirinya, tetapi harus selalu sadar direpoduksi dari satu generasi ke generasi lainnya. Dalam konteks ini ruang lingkupnya bukan hanya menyangkut persoalan penguatan politik dan demokrasi semata, melainkan juga pembentukan warga negara yang dicita-citakan mampu memberikan sumbangsih nyata dalam kehidupan kebangsaan. Hal ini harus dipersiapkan dengan matang melalui jenjang pendidikan di sekolah dengan cara formalisasi melalui mata pelajaran Pendidikan Kewarganegaraan.

Pada konteks lainnya Alexis de Toqueville (Branson, 1998) menyatakan bahwa "setiap generasi baru adalah masyarakat baru yang harus memperoleh pengetahuan, mempelajari keahlian, dan mengembangkan karakter atau watak 
publik maupun privat yang sejalan dengan demokrasi konstitusional". Oleh karena itu sudah selayaknya dilakukan pembinaan sikap dan pembentukan karakter warga negara. Para pemangku kepentingan perlu merangkul pelbagai elemen dalam masyarakat, terutama keterlibatan secara sadar.

Organisasi kemasyarakatan juga harus berperan bersama-sama menjadi teladan pelaksanaan community civics, salah satunya kalangan tradisionalis pesantren yang mempunyai keterkaitan secara integral dengan organisasi NU. Pada hakikatnya kalangan tradisionalis pesantren selalu bergerak maju melampaui spektrum-spektrum penghalang dan cenderung dinamis. Hal itu secara ontologis didasari budaya kewarganegaraan dan kaidah fiqih kaum tradisionalis yang dipegang oleh kalangan pesantren yaitu al-mukhafadzhotu ala al-qodim al-sholih wa alahdzu bi al-jadid alashlah (mempertahankan tradisi dan nilai lama yang masih baik dan mengambil nilai-nilai baru yang lebih baik).

\section{Peran Pesantren sebagai Implementasi Community Civics di Lingkungan Pesantren Al-hikamussalafiyah Purwakarta}

Berdasarkan hasil pengamatan, peneliti mendapati bahwa dalam membina dan membentuk sikap warga negara yang baik dan cerdas, cinta tanah air, demokratis, berkarakter, toleran, dan kompeten, pesantren melakukan hal-hal berikut terhadap para santri; pertama berpatokan kepada ajaran atau faham Islam yang dianut oleh kaum tradisionalis pesantren (civic culture), yaitu faham Islam ahlussunnah waljamaah (ajaran Islam yang diajarkan dan diamalkan oleh Nabi Muhammad SAW) dengan tambahan an-nahdliyah atau ajaran NU.

Ajaran Islam tersebut mempunyai sebuah tradisi keagamaan yang mengakar, bahkan terdapat sebuah modal kultural budaya kewarganegaraan yang kuat dalam pembentukan sikap kaum tradisionalis Nahdliyin. Modal kultural tersebut adalah adalah sikap tawassuth (sikap tengah-tengah/moderat), i'tidal (tegak lurus), tasamuh (toleran), tawazun (seimbang), dan amar ma'ruf nahi munkar (menegakkan yang benar dan melarang yang salah) yang pada akhirnya menjadi legitimasi utama dalam perkembangan menjadi warga negara yang baik dan senantiasa menjaga ukhuwah wathaniyah (persaudaraan bangsa), ukhuwah insaniyah (persaudaraan umat manusia), ukhuwah islamiyah (persaudaraan umat islam). Lebih jauh modal kultural tradisi dan legitimasi tersebut menjadi dasar pokok pikiran pendidikan karakter dalam habituasi santri dan warga nahdliyin pada umumnya.

Kedua, dalam membina dan membentuk santri menjadi warga negara yang baik, selain berpatokan terhadap tradisi keagamaan yang dusung berdasarkan paham dianut, kalangan pesantren juga berpegang kepada legitimasi keputusan keilmuan para ulama atau kyai NU dan ahlussunnah waljamah (para ahli sunnah, fiqih, dll). Salah satu hal lain yang dijadikan sebagai patokan adalah keputusan muktamar dan keputusan mengenai kehidupan kebangsaan lainnya seperti Resolusi Jihad, Piagam Nahdlatul Wathan, Hasil Muktamar dengan rekomendasi yang dibuatnya, Munas Alim Ulama, Konbes dan sebagainya.

Ketiga, metode yang digunakan dalam membentuk santri yang baik dan cerdas adalah dengan menggunakan metode suri tauladan/takzim, dan kedisiplinan dari para guru dan kyai mereka. Pembiasaan-pembiasaan itulah yang akhirnya 
melekat terhadap diri santri bahwa itu adalah sikap yang benar dalam kehidupan sosial sehari-hari bahkan lebih jauh berbangsa dan bernegara. Adapun media yang digunakan dalam membina sikap tersebut adalah pengkajian kitab kuning dan ajaran Islam yang diusung dengan sungguh-sungguh. Kegiatan yang juga penting adalah pelatihan, seminar, serta kewajiban mengikuti organisasi di bawah NU yang mempunyai jenjang pengkaderan yang memasukkan materi-materi tersebut. Ketakziman serta konsep ta'lim mutaalim (belajar dari kitab) di benak santri terhadap kyai dalam tradisi kultural warga nahdliyin merupakan sebuah kepatutan dan keharusan yang tidak bisa di lepaskan. Baik santri ataupun warga nahdliyin umumnya beranggapan bahwa apa yang dilakukan kyai dengan suri tauladannya merupakan contoh yang baik untuk dilakukan.

\section{Habituasi dan dan Implikasi Peran Pesantren dalam Community Civics}

Pembinaan untuk menjadi warga negara yang baik telah dilakukan sepenuhnya oleh pesantren Al-Hikamussalafiyah Cipulus. Salah satu cara yang dilakukan yaitu melalui metode memperdalam ilmu agama berdasarkan faham keagamaan yang dipegang dengan pelbagai metodenya. Hal ini memberikan sebuah legitimasi akan pembinaan sikap tersebut. Pembinaan yang dilakukan memiliki tujuan membentuk pribadi santri menjadi insan (manusia) dan syamil (menyeluruh) serta memiliki sikap kesadaran yang tinggi terhadap bangsa dan negara.

Menurut penuturan pengasuh dan dewan kyai, dengan mondok (belajar dan tinggal di pesantren), para santri bisa bermanfaat dan berperan kelak ketika terjun ke masyarakat. Pasca mondok para santri diharapkan bisa mensyiarkan risalah Islam rahmatan lil 'alamin dengan melakukan transformasi sosiokultural dengan menjadi afdholun nas (transformasi personal), berkumpul sebagai khoiro ummah (transformasi sosial), berkiprah sebagai ummatan wasatha (kiprah kultural), menjawab masalahmasalah sosial secara berkesinambungan dan memiliki peran terciptanya Indonesia yang yang aman makmur.

Peran pesantren dalam melakukan pembiasaan berkaitan dengan habituasi dilakukan para kyai ketika mengaji dan mengkaji kitab para ulama terdahulu, dengan memberikan contoh berdasarkan kontekstualisasinya hari ini. Sebagai contoh, dalam menguatkan semangat kebangsaan dengan mensyukuri kemerdekaan yang telah diraih, santri diberikan nasihat dalam menguatkan nilai persatuan di tengah keberagaman, serta membangun bangsa dan bagaimana harus sepenuh hati mencintai Indonesia. Terdapat juga muatan bagaimana menjadi pemimpin yang baik dan arif, serta cara berlaku adil ketika menjadi pemimpin melalui syair tertentu. Hal ini menunjukkan pendidikan akan penguatan kebangsaan dan juga pendidikan politik yang diberikan oleh para kyai melalui metode keagamaan dengan mengaji.

Peran pesantren sebagai basis kultural Nahdlatul Ulama tidak perlu disangsikan lagi. Apabila dicermati pernyataan di atas, hal-hal seperti penguatan rasa kebangsaan, nasionalisme, patriotisme, penguatan identitas nasional bangsa, perekat entitas bangsa, penjaga moralitas karakter bangsa, bahkan garda terdepan dalam menjaga NKRI telah dilakukan dengan penuh tanggung jawab. Kesimpulan yang peneliti dapati yaitu bahwasanya kalangan pesantren sebagai sebuah subkultur sosial telah memiliki kesadaran akan peran sertanya dalam membentuk 
warga negara yang baik dan cerdas. Kesadaran tersebut justru dikuatkan berdasarkan tradisi dan legitimasi atas faham keagamaannya yang luwes tetapi ketat terhadap nilai tradisi lama. Peneliti menyimpulkan bahwa tidak ada model yang khusus dalam pembiasaan karakter dan sikap terhadap para santri di pesantren Al-Hikamussalafiyah Cipulus.

Pembiasaaan yang dilakukan di pesantren NU pada umumnya dilakukan dengan memegang teguh paham keagamaan dan itulah originalitas yang harus senantiasa dipertahankan. Paham keagamaan yang dipegang menjadi budaya kewargaan, yang secara kontekstual menunjang proses pembinaan yang ditambah dengan keputusan-keputusan keilmuan para kyai dan ulama NU tentang keindonesiaan. Model dan metode pembinaan menjadi warga negara yang baik dilakukan dengan memperdalam ilmu agama, kegiatan pelatihan, seminar, peringatan hari besar, serta pengkaderan melalui organisasi.

Pembinaan yang dilakukan di sekolah yaitu dengan pembiasaan menyanyikan lagu ya lal wathan (pemuda cinta tanah air) karangan K.H Wahab Hasbullah (Wahab, 2011) agar santri bisa mengambil makna dan hikmah dari syiir (karya sastra Arab) tersebut, ditambah dengan sebuah syair yang disebut nadham dan cacarakan karangan Abah Cipulus yang setiap hari dilakukan ketika menjelang waktu mengaji dan salat. Santri juga diwajibkan belajar berorganisasi di badan otonom NU. Setelah peneliti mengamati lebih jauh, setiap pengkaderan mempunyai materi akan penguatan rasa kebangsaan, nasionalisme, patriotisme, penguatan identitas nasional bangsa, serta penguatan moralitas dan karakter warga negara melalui pengajian rutin dan latihan kepemimpinan.

Pemupukan sikap kebangsaan dan hidup berbangsa dalam bingkai keindonesiaan di pesantren Al- Hikamussalafiyah Cipulus melalui pelatihan dan seminar terus dilestarikan. Patut kita cermati bahwasanya kalangan pesantren, apabila merujuk pendapat Sumarsono (2008), telah memiliki "kesadaran yang dipengaruhi oleh lingkungannya, manusia Indonesia memiliki motivasi antara lain untuk menciptakan suasana damai dan tentram menuju kebahagiaan serta menyelenggarakan keteraturan dalam membina antar sesama". Habituasi peran pesantren Al- Hikamussalafiyah dalam membina dan membentuk sikap warga negara yang baik dapat dijelaskan dalam tabel triangulasi teknik pengumpulan data sebagai berikut.

\section{Tabel 1. Tabel Triangulasi Data}

\begin{tabular}{|c|c|c|}
\hline Hasil Wawancara & Hasil Observasi & Studi Literatur \\
\hline $\begin{array}{l}\text { Bentuk pembiasaan yang } \\
\text { paling utama adalah } \\
\text { dengan mengaji, menelaah } \\
\text { berbagai kitab kuning, } \\
\text { hadist, tassawuf dan fiqih, } \\
\text { serta ditunjang melalui } \\
\text { keaktifan di organisasi yang } \\
\text { berada dalam naungan NU, } \\
\text { seminar, dan pelatihan. }\end{array}$ & $\begin{array}{ll}\text { a. } & \text { Pembinaan dengan } \\
\text { mengaji dan mengkaji } \\
\text { ilmuagama. } \\
\text { b. Muhadharah, nadhaman dan } \\
\text { cacarakan yang memiliki } \\
\text { pesan kehidupan } \\
\text { kebangsaan karangan } \\
\text { Abah Cipulus. } \\
\text { c. Pembiasaan menyanyikan } \\
\text { lagu ya lal wathan }\end{array}$ & $\begin{array}{lr}\text { Sikap } & \text { kebangsaan } \\
\text { merupakan } & \text { unsur kunci } \\
\text { dalam menjamin } & \text { heterbukaan } r \text { hakiki } \\
\text { masyarakat terhadap } \\
\text { kekayaan nilai-nilainya, } \\
\text { yang merupakan modal } \\
\text { dasar untuk hidup } \\
\text { bersama dengan baik dan } \\
\text { sinergik" } & \text { (Suseno, M, }\end{array}$ \\
\hline
\end{tabular}




\begin{tabular}{|l|l|l|}
\hline & $\begin{array}{l}\text { (pemuda cinta tanah air). } \\
\text { d. } \begin{array}{l}\text { Pengarahan komitmen } \\
\text { kebangsaan dan ke- }\end{array}\end{array}$ \\
& $\begin{array}{l}\text { Indoneisa-an. } \\
\text { e. Seminar dan pelatihan }\end{array}$ & \\
f. Pengkaderan di setiap & \\
badan otonom NU & \\
\hline
\end{tabular}

Sumber: data olahan peneliti

Sebagai bagian dari masyarakat Indonesia, kalangan pesantren Nahdliyin terus konsisten dan bertekad untuk terikat dengan kesepakatan nasional yang telah mengatur kehidupan baik dalam masyarakat, berbangsa, dan bernegara, serta diwujudkan dalam realitas kehidupan sosial. Meskipun demikian kalangan pesantren/santri memandang prinsip berbangsa dan bernegara harus tetap menghargai dan menghormati keyakinan keberagaman di tengah masyarakat. Kiprah organisasi NU yang berbasis pondok pesantren adalah kemanusiaan, keislaman dan keindonesiaan yang rahmatan lil alamin. Selain itu NU dan pesantren Al- Hikamussalafiyah Cipulus meneguhkan kultur, struktur, dan sistem mekanisme lembaganya sebagai organisasi sosial keagamaan yang mempunyai ciri ahlussunnah wal jamaah. Penanaman sikap kesadaran berbangsa dan cinta tanah air diharapkan menciptakan warga negara yang utuh secara sepenuh hati mencintai negaranya. Ini sejalan dengan pendapat Kohn, (1984) "nasionalisme sebagai suatu paham yang berpendapat bahwa kesetiaan tertinggi suatu individu harus diserahkan kepada negara dan bangsa".

Menurut pandangan santri dan pengurus, dengan melihat teladan yang diberikan guru, santri akan menganggap sikap itu adalah yang benar karena ketakzimannya dan ta'lim terhadap guru. Keteladanan itulah yang menjadi kunci dalam membina sikap, dan secara psikologis manusia memerlukan keteladanan untuk mengembangkan sifat dan potensinya. Pendidikan keteladanan adalah pendidikan dengan cara memberikan contoh konkrit pada para santri, khususnya dalam pesantren. Pemberian contoh keteladanan sangat ditekankan dan menjadi kultur keilmuan tersendiri di kalangan Islam tradisionalis. Kiyai harus senantiasa memberikan uswah yang baik bagi para santri baik dalam ibadah-ibadah ritual maupun kehidupan sehari-hari, sebab nilai mereka ditentukan dari aktualisasinya terhadap apa yang disampaikan. Semakin konsekuen seorang kiyai menjaga tingkah lakunya, semakin didengar ajarannya.

Pembiasaan lainnya menurut mereka ditunjang dengan pelatihan kepemimpinan, seminar, dan keaktifan di organisasi, sehingga sebagian besar santri ikut menjadi pengurus badan otonom NU seperti Gerakan Pemuda (GP) Ansor, organiasi pemudi Fatayat, Ikatan Pelajar Nahdlatul Ulama (IPNU), dan Ikatan Pelajar Putri Nahdlatul Ulama (IPPNU). Di organisasi, mereka juga diberikan pembinaan dan pembentukan sikap seperti mengawal kehidupan yang demokratis, toleran, serta mampu berperan dalam memahami, menganalisa, dan menjawab problematika yang dihadapi oleh masyarakat. Salah satu contoh kegiatan tersebut adalah dialog kepemudaan dan kebhinekaan yang dilakukan dengan berbagai organisasi kepemudaan lain yang pluralistik seperti yang dilakukan Komite 
Nasional Pemuda Indonesia (KNPI), Forum Kerukunan Umat Beragama (FKUB), atau GP Ansor. Secara praktis, para santri yang aktif di organisasi otonom NU selalu diikutsertakan pemerintah daerah di pelbagai pembangunan daerah khususnya bidang kepemudaan dan keagamaan dalam menjaga moralitas karakter masyarakat. Dengan demikian kalangan tradisionalis NU dengan basis kultural pesantren telah memilik modal dan prinsip kemasyarakatan bersama dan telah mampu menyesuaikan bahkan menyelaraskan antara nilai keagamaan dan keindonesiaan yang tak lagi hanya membatasi diri pada upaya pemecahan masalah-masalah yang menyangkut kepentingan warga nahdliyin saja, tetapi juga mencakup kepentingan bangsa. NU sendiri untuk saat ini mengakui bahwa wilayah esensi bagi sebuah komunitas yang mandiri kini menjadi salah satu komitmen utama perjuangan" (Dharwis, Ellyasa, 1994).

Dari gagasan tradisi dan legitimasi keagamaan tersebut dapat dimaknai bahwa pesantren dan NU sebagai sebuah civic community memiliki peran penting dalam membentuk karakter bangsa dan membina warga negara Indonesia agar memahami tugas serta tanggung jawabnya dalam kehidupan berbangsa bernegara. Pembangunan karakter melalui gerakan sosial kultural tersebut menjadi sangat penting dan unik. Pelaksanaannya disesuaikan dengan nilai luhur yang dipegang serta tuntutan menciptakan warga negara yang baik dan cerdas.

\section{SIMPULAN}

Membentuk karakter warga negara yang baik dan cerdas, memiliki kesadaran yang tinggi akan kehidupan kebangsaan, berkompetensi serta mampu berkiprah dalam mengurai problematika sosial kemasyarakatan bukan hanya tugas pemerintah dengan lembaga pendidikannya melalui Pendidikan Kewarganegaraan secara formal, tetapi juga pihak-pihak di luar pendidikan formal. Hal ini ditunjukkan oleh ruang lingkup kewarganegaraan kemasyarakatan (community civics) dalam PKn. Deformalisasi menjadi penting dan menjadi tanggung jawab bersama dalam membentuk warga negara yang baik dan cerdas bagi ruang lingkup sosial komunitasnya.

Di masa yang akan datang, sinergi antara formalisasi dan deformalisasi PKn harus selalu beriringan satu sama lainnya. Deformalitas PKn perlu kita dorong agar setiap institusi/lembaga/perusahaan/organisasi kemasyarakatan/komunitas memiliki peran dan tanggung jawab dalam membangun kompetensi warga negara itu sendiri. Di sinilah peran segenap warga bangsa ikut andil dan saling mengisi kekurangan satu sama lainnya. Peran tersebut diharapkan memberikan pengaruh signifikan dalam fundamen kehidupan bersama sebagai sebuah bangsa untuk mencapai tujuan yang di cita-citakan.

Nahdlatul Ulama sudah lama berperan terhadap bangsa ini seperti penguatan rasa kebangsaan dan patriotisme warga negara, penguatan identitas nasional bangsa, perekat entitas bangsa, penjaga moralitas karakter bangsa, bahkan garda terdepan dalam menjaga NKRI. Sebagai sebuah organisasi kemasyarakatan yang tidak bisa dipisahkan dari lembaga kependidikan, pesantren juga telah mampu menjadi teladan dalam implementasi community civics baik sebagai oganisasi maupun lembaga kependidikan. Tradisi keilmuan yang dipegang teguh mampu 
disinergikan dengan kehidupan sosial kemasyarakatan dan kebangsaan dalam membentuk karakter warga nahdliyin dan santri khususnya di lingkungan Pesantren Al-Hikamussalafiyah Cipulus Purwakarta. Modal kultural tersebut adalah sikap tawassuth, tasamuh, tawazun, dan amar ma'ruf nahi munkar. Modal tersebut menjadi sebuah legitimasi utama tentang bagaimana menjadi warga negara yang baik. Ini juga menjadi dasar pokok pikiran pendidikan karakter santri bahkan warga nahdliyin umumnya. Para santri Al-Hikamussalafiyah Cipulus pasca mondok lebih jauh bisa mensyiarkan risalah Islam rahmatan lil 'alamin dengan melakukan transformasi sosiokultural membangun peradaban dengan menjadi afdholun nas (transformasi personal), berkumpul sebagai khoiro ummah (transformasi sosial), berkiprah sebagai ummatan wasatha (kiprah kultural), dengan harapan bisa memahami, menganalisa, dan menjawab problematika sosial yang dihadapi masyarakat secara berkesinambungan dan memiliki peran agar tercipta Indonesia yang adil dan makmur.

Penelitian-penelitian tentang deformalisasi PKn melalui organisasi kemasyarakatan harus ditingkatkan untuk menutupi kekuarangan kajian yang ada hari ini. Padahal apabila dikaji lebih jauh, PKn memiliki muatan yang sangat luas dan bukan hanya pembelajaran formal saja. Untuk para peneliti selanjutnya yang ingin mengkaji NU sebagai implementasi community civics disarankan terlebih dahulu untuk mengkaji konteks berpikirnya tersebut berdasarkan pada budaya kewargaan atau kaidah keilmuan pemikiran kaum santri, khususnya berdasar pada tradisi ajaran Islam ahlussunnah wal jamaah dalam pandangan kaum santri serta keputusan para kyai NU terdahulu berdasarkan keputusan sikapnya.

\section{REFERENSI}

Ahadi, M. (2017). Peran Pembelajaran Pendidikan Kewarganegaraan dalam Menumbuhkan Sikap Bela Negara. Prosiding Seminar Nasional Tahunan Fakultas Ilmu Sosial Universitas Negeri Medan, Vol. 1(No. 1 2017), 520-525.

Branson, M. S. (1998). The Role of Civic Education: A Forthcoming Education Policy Task Force. Position Paper from The Communitarian Network, Calabasas: CCE.

Budimansyah. (2010). Penguatan Pendidikan Kewarganegaraan Untuk Membangun Karakter Bangsa. Widya Aksara Press.

Dharwis, Ellyasa, dkk. (Editor). (1994). Gus Dur NU dan Masyarakat Sipil. PT. LKIS Printing Cemerlang.

Fahmi, R. (2020). Faktor-Faktor Determinan Peningkatan Tanggung Jawab Warga Melalui Aktualisasi Kebijakan. Jurnal Pelita: Penelitian Dan Karya Ilmiah, 20(No. 2).

Good, C.V(1959). Dictionary Of Education. New York: McGraw-Hill.

Kohn, H. (1984). Nationalisme Arti dan Sejarahnya. Jakarta: Erlangga.

Lubis, F, A, N. (2006). Multikulturalisme Dalam Politik: Sebuah Pengantar Diskusi. Jurnal Antropologi Sosial Budaya Etnovisi, VOL. II (No. 1 April 2006), hal 24-26.

Muchtar. (2006). Dasar Penelitian Kualitatif. Bandung: Gelar Potensi Mandiri.

Peraturan Mentri Dalam Negeri Nomor 71 Tahun 2012. Pendoman Pendidikan Wawasan Kebangsaan. Universitas Pendidikan Indonesia. 
Praja, W, N. (2015). Pembinaan Kesadaran Warga Negara Dalam Melestarikan Lingkungan Hidup (The Living Empironment) Pada Mayarakat Adat Kuta (Tesis). Departemen Pendidikan Kewarganegaraan, Universitas Pendidikan Indonesia.

Rohani. (2015). Urgensi Pembinaan Tanggung Jawab Warga Negara Melalui Comunity Civics. Jurnal : Pendidikan Sosial, Vol. 2(No. 2), hal. 221-234.

Rusnaini. (2018). Prosiding Seminar Nasional PPKn 2018 FKIP Universitas Sebelas Maret.

Sumantri, E. (2010). Makalah: Pendidikan Kewarganegaran Masyarakat (Community Civics). Tidak Diterbitkan.

Sumarsono, (Penyusun). dkk. (2008). Pendidikan Kewarganegaraan. Jakarta: PT Gramedia Pustaka Utama.

Suseno, M, F. (2006). Berebut Jiwa Bangsa. Jakarta: PT Kompas Media Nusantara.

Wahab, S. (2011). Teori dan Landasan Pendidikan Kewarganegaraan. Bandung: Alfabeta.

Winataputra. (2012). Pendidikan Kewarganegaraan Dalam Perseptif Pendidikan Untuk Mencerdaskan Kehidupan Bangsa (Gagasan, Instrumentasi, dan Praksis). Bandung: Widya Aksara Press.

Yin, K, R. (2011). Studi Kasus: Desain dan Metode. Jakarta: PT Rajagrafindo. 